\title{
UPTAKE OF SELECTED HEAVY METALS AND THEIR EFFECTS ON SOME PHYSIOLOGIC PARAMETERS AND MINERAL NUTRITION IN PHRAGMITES AUSTRALIS IN KARASU RIVER-TURKEY
}

\author{
OSMA E. ${ }^{1, *}$ \\ ILHAN V. ${ }^{1}$ \\ YALCIN I.E. ${ }^{2}$
}

\author{
${ }^{1}$ Erzincan University, Faculty of Arts and Sciences \\ Department of Biology, Erzincan-Turkey \\ ${ }^{2}$ Bahcesehir University, Faculty of Engineering and Natural Sciences, \\ Department of Molecular Biology and Genetics, Besiktas, Istanbul-Turkey
}

Received: 03/05/2014

Accepted: 28/06/2015

Available online: 25/08/2015 *to whom all correspondence should be addressed: e-mail: eosma@erzincan.edu.tr

\begin{abstract}
Water contamination by heavy metals is a serious global problem due to increased environmental and health-related issues. In this study, we have comparatively investigated the heavy metal concentrations and mineral nutrient levels in Karasu river sediments and in plants samples of Phragmites australis (Cav.) in order to assess the biomonitoring capacity. Plant and sediment samples were collected from four different localities along Karasu River, and those samples were analyzed in terms of heavy metals such as $\mathrm{Fe}, \mathrm{Zn}, \mathrm{Mn}, \mathrm{Ni}, \mathrm{Cr}, \mathrm{Cu}, \mathrm{Pb}, \mathrm{Co}$ and $\mathrm{Cd}$, and in terms of mineral elements such as $\mathrm{K}, \mathrm{Ca}, \mathrm{Mg}, \mathrm{Na}, \mathrm{Al}$, and $\mathrm{B}$ using ICP-OES. In addition, lipid peroxidation, chlorophyll and carotenoid levels in plant samples were also checked. Sediments in Karasu River contained high concentrations of $\mathrm{Ni}$ and $\mathrm{Cr}$ metals. Moreover, $\mathrm{P}$. australis showed hyper-accumulation for $\mathrm{Cd}$ and $\mathrm{Zn}$ in root and leaf samples, respectively. Although there was no significant difference in chlorophyll amounts among locations, lipid peroxidation was found to be high in samples taken from iliç.
\end{abstract}

Keywords: Chlorophyll; Lipid peroxidation; Heavy Metals; Sediment; Phragmites australis

\section{Introduction}

In recent years, water contamination by heavy metals has become a serious global problem due to increased environmental and health-related issues. The amount of heavy metals in aquatic ecosystems has significantly increased related to anthropogenic and industrial activities (Akguc et al., 2010). Heavy metals do not decrease autogenously, but to accumulate in aquatic micro and macrophytes, and enter into the food chain (Dirilgen, 2011). Many sensitive aquatic vascular plants accumulate metal ions, therefore, they are recognized as biomonitors for metals (Fargasova, 2001; Dhir et al., 2009; Dirilgen, 2011). High concentrations of pollutants have direct and indirect effects on aquatic ecosystems. Heavy metals are one of the main pollutants and moreover, they are both accumulative and highly mobile (Monferrán, 2012). Metals contaminate ecosystems through domestic, industrial and agricultural activities (Demirezen et al., 2007; Yasar et al., 2010; Monferrán, 2012). Using biological materials in environmental cleaning is a quite cheap and reliable method of decontamination. Biomonitors are organisms that provide quantitative information on environmental pollution levels (Markert et al., 2003; Akguc et al., 2008; Aksoy et al., 2012).

$P$. australis is a rather common macrophyte in aquatic ecosystems. Biomonitoring studies have demonstrated that $P$. australis has a bioaccumulation capacity for trace elements (Lesage et al., 2007; 
Vymazal et al., 2007; Fawzy et al.,2012; Bonanno, 2012). Heavy metals such as Zn, Cu and Ni are trace elements and they play important roles in plant growth and development. However, high concentrations are toxic to the plants (Rengel, 2004; Bragato et al., 2009). On the other hand, dispensable elements such as $\mathrm{Cd}, \mathrm{Cr}$, and $\mathrm{Pb}$, could have toxic effects on plants even at low concentrations (Kabata-Pendias and H. Pendias, 1992; Zayed and Terry, 2003). Decontamination of areas with medium levels of contamination is effective and reasonable (Bose, 2008). Effective improvement methods have also been developed for the less contaminated areas (Weis and Weis, 2004; Bose, 2008). Contrary to organic pollutants, decontamination of heavy metals requires extremely expensive methods. Therefore, using plants that have phytoremediation properties stand as potential means to reduce the decontamination costs (Lasat, 2002; Ghosh and Singh, 2005; Bragato, 2009). Macrophytes are common plant species that serve as biomonitors (Demirezen and Aksoy, 2006; Vymazal et al., 2007; Bonanno 2012). Phragmites australis (common reed) is one of the most common macrophytes in aquatic ecosystems, and also several studies have proved its capacity of trace element bioaccumulation (Duman et al., 2007; Bragato et al., 2009; Maddison et al., 2009)

In this study, we have comparatively investigated the heavy metal concentrations and mineral nutrient levels in Karasu river sediments and in $P$. australis plant samples to assess the biomonitoring capacity of $P$. australis. In addition, some physiological features such as lipid peroxidation and chlorophyll amounts of $P$. australis collected from different locations were comparatively analyzed.

\section{Materials and methods}

\subsection{Plant ecology and morphology}

$P$. australis is common in lakes, rivers, swamps, ditches and on the coasts. It can be found approximately at maximum height of 2400 meters. It is a perennial plant with one stem of about 3 meters. The plumes are like hair shape and thick on the ligula. The height of a plume is $0.5-1 \mathrm{~mm}$. The leaf is knife-shaped on the base and approximately $3 \mathrm{~cm}$ wide, and reaches up to $60 \mathrm{~cm}$ long. Panikul is almost $40 \mathrm{~cm}$ and there are more feathers on the base. Each spike includes 3-6 flowers (Davis, 1965).

$P$. australis, known as common reed, is a kind of perennial grass living in the lakes and rivers or brackish wetlands such as marshes across the temperate and tropical regions all over the world. It belongs to Poaceae family and is included among the most common species of the Phragmites genus (Bonanno, 2011). These species prefer eutrophic and stagnating waters and can tolerate to a moderate level of salinity It is a rhizomatous hemicryptophyte/geophyte and creates large areas known as reed beds that provide microhabitats for many birds and mammals (Bonanno, 2011)

\subsection{Study location}

The River Euphrates has the highest water potential in Turkey. It originates from Eastern Anatolia of Turkey and joins into Karasu and Murat Rivers. The River Murat joins in Euphrates at $720 \mathrm{~km}$ away from its source, whereas River Karasu joins at $460 \mathrm{~km}$ away from its source. The total length of Euphrates is $2.800 \mathrm{~km}$, of which $1.263 \mathrm{~km}$ are within Turkey. After leaving the borders of Turkey and joining with River Dicle, Euphrates merges into the Basra Gulf (Anonymous, 2012). The River Karasu goes through Tercan, Erzincan, Kemah and iliç, which are located in Eastern Anatolian of Turkey.

\subsection{Sample collection and analysis}

Plant and sediment samples have been collected from these places where River Karasu flows during July-August 2012 (Fig. 1). Plant samples were divided into root, stem and leaf. Sediment samples were air-dried on floor. Plant materials were oven dried at $80^{\circ} \mathrm{C}$ for $24 \mathrm{~h}$, milled in a micro-hammer cutter and then sieved. After each milling, to protect plant sample from microbial decomposition, mortar was cleaned with ethyl alcohol and distilled water. To ensure the uniform distribution of metals in sample, materials were milled in a micro-hammer cutter, sieved through a $1.5-\mathrm{mm}$ sieve and kept in clean polyethylene bags (Markert, 1993; Osma et al., 2012). Lipid peroxidation level was measured using 
Heath and Packer method (1968) with slight modifications (Ananieva et al., 2002). $0.5 \mathrm{~g}$ leaf sample was homogenized in $3 \mathrm{ml} 0.1 \%$ TCA and centrifuged at $15000 \times \mathrm{g}$ for $30 \mathrm{~min}$ at $4{ }^{\circ} \mathrm{C}$. To $0.5 \mathrm{ml}$ aliquot of the supernatant, $1 \mathrm{ml}$ reagent $(0.5 \%$ thiobarbituric acid (TBA) in $20 \%$ TCA, w/v) was added. For a negative control, $0.5 \mathrm{~mL} 0.1 \%$ TCA and $1 \mathrm{ml}$ reagent were added. The test-tubes were heated at $95^{\circ} \mathrm{C}$ for $30 \mathrm{~min}$ and then quickly cooled in an ice bath. After cooling and centrifugation to give a clear supernatant, absorbance of supernatant was read at $532 \mathrm{~nm}$ and value for the non-specific absorption at $600 \mathrm{~nm}$ was subtracted. The level of malondialdehyde (MDA) was estimated by using the $\mathrm{mmol} / \mathrm{L}$ extinction coefficient of $155 \mathrm{mmol} / \mathrm{L}^{-1} \mathrm{~cm}^{-1}$ (Mutlu et al., 2011, 2012).

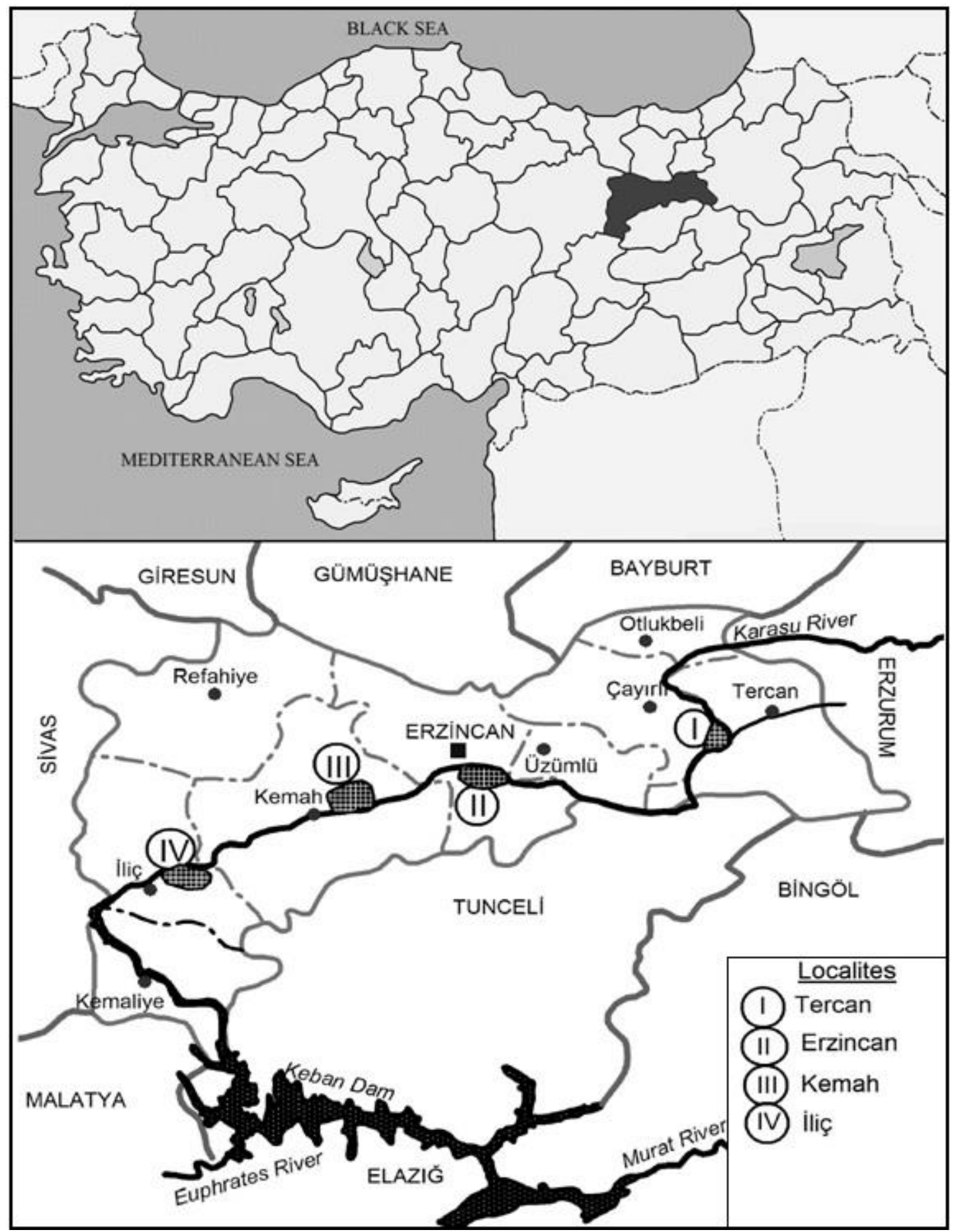

Figure 1. Location of study area 
Total chlorophyll and carotenoid content in fresh leaves were estimated using Lichtenthaler and Buschmann method (2001). $0.5 \mathrm{~g}$ fresh leaf tissue was ground in a mortar containing $5 \mathrm{ml}$ acetone (80\%). The optical density of solution was read at 662 and $645 \mathrm{~nm}$ (chlorophyll) and $470 \mathrm{~nm}$ (carotenoids). Photosynthetic pigments were expressed as $\mathrm{mg} / \mathrm{g}^{-1} \mathrm{FW}$ (Erdal2012).

Plant samples were then added to $8 \mathrm{ml} 65 \% \mathrm{HNO}_{3}$ (Merck), soil samples were added to $5 \mathrm{ml} 65 \% \mathrm{HNO}_{3}$, $3 \mathrm{ml} 37 \% \mathrm{HCl}$ and $2 \mathrm{ml} 48 \% \mathrm{HF}$. Teflon plates were closed, then placed in a microwave oven (Berghof MWS2). The heat of the microwave was gradually increased to $175^{\circ} \mathrm{C}$ and held for 20 minutes. Then, the Teflon plates were filtered with Whattman filters into $50-\mathrm{ml}$ sterile tubes and were added up to 50 $\mathrm{ml}$ by using ultra-pure water. Finally, these samples were made ready for element analysis with ICPOES (Inductively Coupled Plasma Optical Emission Spectroscopy - Perkin Elmer-Optima 7000 DV). Before analyzing, standards were prepared using 1000 ppm multi-element solution (Merck). Elemental analysis was conducted with ICP-OES (Aksoy and Ozturk, 1996; Osma et al., 2012).

\subsection{Data analysis}

Statistical comparisons were significant at $\leq 0.05$. To determine the standard deviation, ANOVA test were used. Tukey HSD tests were used to determine differences in multiple comparison test. In addition, correlations were examined between lipid peroxidation in plant samples (Osma et al., 2012).

\section{Results and discussion}

In the present study, we have analyzed the concentrations of heavy metals and mineral elements in sediment and in $P$. australis samples collected from along the Karasu River. In addition, we have analyzed the lipid peroxidation, chlorophyll and carotenoid levels in plant samples. In this study, nine heavy metals and six mineral elements, in total, 15 metals were analyzed. The heavy metal concentrations in sediment and plant samples showed following sequence:

In sediment: $\mathrm{Fe}>\mathrm{Mn}>\mathrm{Ni}>\mathrm{Cr}>\mathrm{Zn}>\mathrm{Co}>\mathrm{Cu}>\mathrm{Pb}>\mathrm{Cd}$;

In root: $\mathrm{Zn}>\mathrm{Fe}>\mathrm{Mn}>\mathrm{Ni}>\mathrm{Cr}>\mathrm{Cu}>\mathrm{Pb}>\mathrm{Co}>\mathrm{Cd}$;

In stem and leaf: $\mathrm{Fe}>\mathrm{Zn}>\mathrm{Mn}>\mathrm{Ni}>\mathrm{Cr}>\mathrm{Cu}>\mathrm{Pb}>\mathrm{Co}>\mathrm{Cd}$ (Figure 2).

The concentrations of mineral elements in sediments and plants samples were ranked as follows:

In sediment: $\mathrm{Al}>\mathrm{Mg}>\mathrm{Ca}>\mathrm{K}>\mathrm{Na}>\mathrm{B}$;

In root, stem and leaf: $\mathrm{K}>\mathrm{Ca}>\mathrm{Mg}>\mathrm{Na}>\mathrm{Al}>\mathrm{B}$ (Figure 2).

Statistical analysis showed the differences between element concentrations (Figure 2). While Al showed high concentration in sediment, its uptake by $P$. australis was quite low. Concentration of $\mathrm{K}$ in sediment was lower than that of plant parts, especially compared to the concentration in the leaf samples. Among mineral elements, Ca was the second element in plant samples after $\mathrm{K}$.

There were differences in heavy metal concentrations between upper and lower sides of the river. In particular, sediment samples showed higher concentrations of $\mathrm{Ni}$ and $\mathrm{Cr}$. Concentrations of $\mathrm{Cd}$ and $\mathrm{Zn}$ were higher in sediments than in the plant samples.

Varol (2011) reported higher $\mathrm{Cd}\left(1.2-4.9 \mu \mathrm{gg}^{-1} \mathrm{dw}\right), \mathrm{Mn}\left(282-1,657 \mu \mathrm{gg}^{-1} \mathrm{dw}\right), \mathrm{Pb}\left(62-566 \mu \mathrm{gg}^{-1} \mathrm{dw}\right)$ and $\mathrm{Zn}\left(123-2,396 \mathrm{\mu gg}^{-1} \mathrm{dw}\right)$ levels in sediment, but $\mathrm{Ni}, \mathrm{Cr}$ and $\mathrm{Co}$ were parallel with our results. Bonanno (2011) found higher $\mathrm{Al}\left(21,600 \mu \mathrm{gg}^{-1} \mathrm{dw}\right)$ and $\mathrm{B}\left(<0.5 \mu \mathrm{gg}^{-1} \mathrm{dw}\right)$ concentrations in plant material but lower values in sediment; the concentration of Co was similar to the present study, whereas Fe was higher in sediment but similar in plant material. Vymazal (2009) reported higher values for Al (188 $\mathrm{ugg}^{-}$ $\left.{ }^{1} \mathrm{dw}\right)$, Fe $\left(109 \mu \mathrm{gg}^{-1} \mathrm{dw}\right), \mathrm{B}\left(5.2 \mu \mathrm{gg}^{-1} \mathrm{dw}\right)$, and $\mathrm{Mn}\left(175 \mu \mathrm{gg}^{-1} \mathrm{dw}\right)$ but lower values for metals such as $\mathrm{Cr}\left(0.18 \mu \mathrm{gg}^{-1} \mathrm{dw}\right), \mathrm{Cd}\left(0.01 \mu \mathrm{gg}^{-1} \mathrm{dw}\right), \mathrm{Ni}\left(1.63 \mu \mathrm{gg}^{-1} \mathrm{dw}\right), \mathrm{Pb}\left(0.23 \mu \mathrm{gg}^{-1} \mathrm{dw}\right), \mathrm{Co}\left(0.08 \mu \mathrm{gg}^{-1} \mathrm{dw}\right)$ and $\mathrm{Zn}$ (27.1 $\mathrm{\mu gg}^{-1} \mathrm{dw}$ ). Bonanno (2012) studied Arundo donax, and reported lower concentrations of Mn (815 $\left.\mu \mathrm{gg}^{-1} \mathrm{dw}\right), \mathrm{Cr}\left(19.2 \mu \mathrm{gg}^{-1} \mathrm{dw}\right)$ and $\mathrm{Ni}\left(17.5 \mu \mathrm{gg}^{-1} \mathrm{dw}\right)$; similar levels of $\mathrm{Cd}$; and $\mathrm{Pb}$ and $\mathrm{Zn}$ in sediment but similar levels to the present study in the plant material. When (Bonanno and Giudice, 2010)'s research results were examined, in sediment, $\mathrm{Cd}\left(0.66 \mu \mathrm{gg}^{-1} \mathrm{dw}\right), \mathrm{Mn}\left(181.8 \mu \mathrm{gg}^{-1} \mathrm{dw}\right)$ were lower than our data; 
$\mathrm{Cu}$ and $\mathrm{Pb}$ were parallel with ours; $\mathrm{Zn}\left(9.69 \mu \mathrm{gg}^{-1} \mathrm{dw}\right), \mathrm{Ni}\left(29.14 \mu \mathrm{gg}^{-1} \mathrm{dw}\right), \mathrm{Cr}\left(40.1 \mu \mathrm{gg}^{-1} \mathrm{dw}\right)$ were lower than our findings, however, in the parts of $P$. australis $\mathrm{Cd}\left(0.68-1.13 \mu \mathrm{gg}^{-1} \mathrm{dw}\right)$ and $\mathrm{Pb}(9.87-16.54$ $\mu \mathrm{gg}^{-1} \mathrm{dw}$ ) were higher than our results, $\mathrm{Cu}$ and $\mathrm{Zn}$ was parallel with our values again; $\mathrm{Cr}$ (0.40-6.97 $\mu \mathrm{gg}^{-}$ ${ }^{1} \mathrm{dw}$ ) were lower than ours. Bragato (2006) studied P. australis, and reported similar $\mathrm{Cr}$ and $\mathrm{Cu}$ levels but lower $\mathrm{Ni}$ and $\mathrm{Zn}$. A study by Demirezen and Aksoy (2004) was compared with our results, in this study, it was pointed out that $\mathrm{Cd}$ was higher; $\mathrm{Cu}, \mathrm{Pb}$ and $\mathrm{Zn}$ were parallel with our values but $\mathrm{Cr}$ (1-12 $\mu \mathrm{gg}^{-1} \mathrm{dw}$ ) and $\mathrm{Ni}\left(2-12 \mu \mathrm{gg}^{-1} \mathrm{dw}\right.$ ) were lower. Singha (2003) reported higher $\mathrm{Cr}, \mathrm{Mn}, \mathrm{Fe}, \mathrm{Cu}, \mathrm{Zn}$ and $\mathrm{Pb}$ levels; Co and Cd were parallel, whereas Ni was lower than our findings. Samecka-Cymermana and Kempers (2004) reported higher concentrations of Zn (246-515 $\left.\mu \mathrm{gg}^{-1} \mathrm{dw}\right), \mathrm{Ca}\left(12.900-19.200 \mu \mathrm{gg}^{-1} \mathrm{dw}\right)$, Fe (14.200-25.200 $\left.\mu^{-1} g^{-1} \mathrm{dw}\right)$, Al (147-354 $\left.\mathrm{\mu gg}^{-1} \mathrm{dw}\right), \mathrm{Cd}\left(1.1-8.8 \mu \mathrm{gg}^{-1} \mathrm{dw}\right), \mathrm{Co}\left(33-98 \mu \mathrm{gg}^{-1} \mathrm{dw}\right), \mathrm{Cu}(720-$ $\left.1.040 \mu g^{-1} \mathrm{dw}\right), \mathrm{Mn}\left(3,990-6,660 \mu \mathrm{gg}^{-1} \mathrm{dw}\right), \mathrm{Ni}\left(18-59 \mu \mathrm{gg}^{-1} \mathrm{dw}\right)$ and $\mathrm{Pb}\left(151-850 \mu \mathrm{gg}^{-1} \mathrm{dw}\right)$ heavy metals in plants than those in the resent study, whereas $\mathrm{Mg}\left(1,730-5,260 \mathrm{\mu gg}^{-1} \mathrm{dw}\right)$ and $\mathrm{Cr}\left(1.3-2.7 \mu \mathrm{gg}^{-}\right.$ ${ }^{1} \mathrm{dw}$ ) similar to our findings. Obolewski (2011) reported higher levels of $\mathrm{Cd}\left(1.3-2.1 \mu^{-1} \mathrm{gg}^{-1} \mathrm{dw}\right), \mathrm{Pb}$ (14.4$\left.26 \mu \mathrm{gg}^{-1} \mathrm{dw}\right)$, Fe $\left(97-333 \mu \mathrm{gg}^{-1} \mathrm{dw}\right), \mathrm{Na}\left(501-12,454 \mu \mathrm{gg}^{-1} \mathrm{dw}\right)$ and $\mathrm{Ca}\left(5,686-10,285 \mu \mathrm{gg}^{-1} \mathrm{dw}\right)$ than the present study; Zn (8.6-44.4 $\left.\mathrm{gg}^{-1} \mathrm{dw}\right), \mathrm{Cu}\left(1.5-11.1 \mu \mathrm{gg}^{-1} \mathrm{dw}\right)$ and Co $\left(3-5 \mu \mathrm{gg}^{-1} \mathrm{dw}\right)$ were lower than ours, whereas $\mathrm{Cr}, \mathrm{Ni}, \mathrm{Mn}, \mathrm{K}$ and $\mathrm{Mg}$ were parallel with our findings.
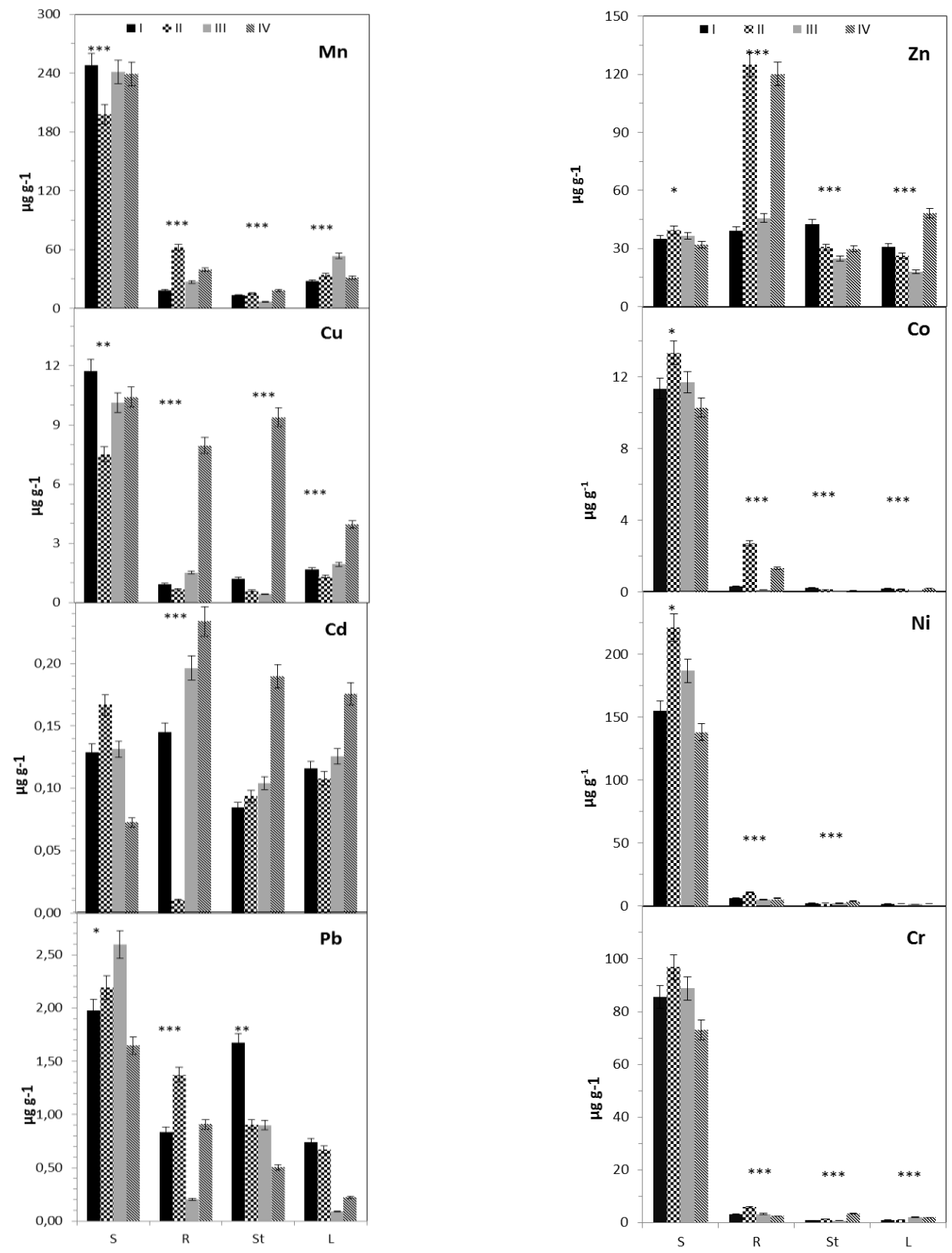

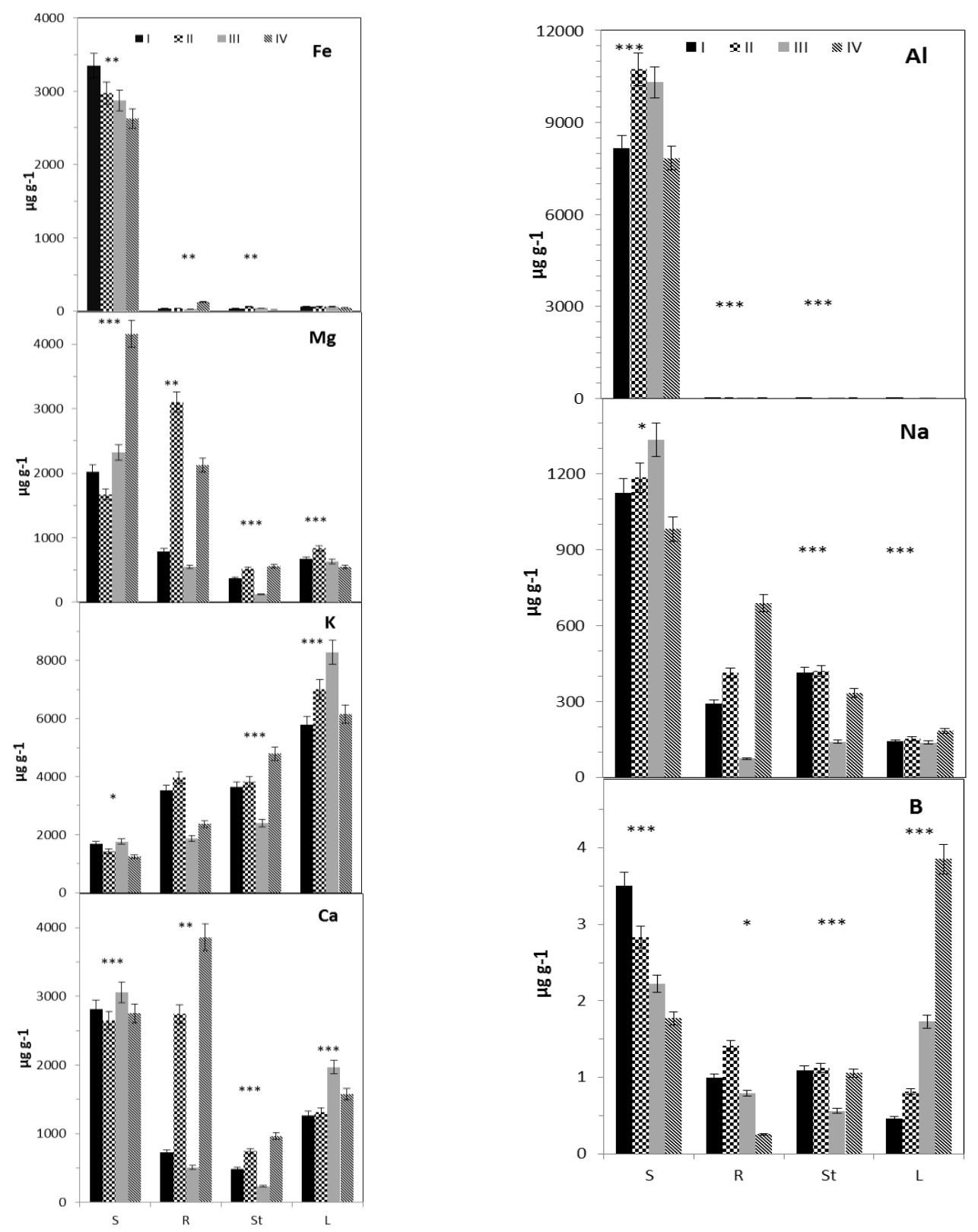

Figure 2. The concentration of $\mathrm{Mn}, \mathrm{Cu}, \mathrm{Cd}, \mathrm{Pb}, \mathrm{Zn}, \mathrm{Co}, \mathrm{Ni}, \mathrm{Cr}, \mathrm{Fe}, \mathrm{Mg}, \mathrm{K}, \mathrm{Ca}, \mathrm{Al}, \mathrm{Na}$ and $\mathrm{B}$. Significance of differences between sediment, root, stem and leaf from paired t-test, are indicated above the columns. (Keys: ${ }^{*} p<0.05 ;{ }^{* *} p<0.01 ;{ }^{* * *} p<0.001$ significant; I, Tercan, II, Erzincan, III, Kemah, IV, iliç and S, sediment, R, root, St, Stem, L, leaf)

The concentrations of metals obtained from the plant measurements in this study were parellel reported by Ross (1994), and Kacar and Inal (2008), but there are important differences between localities.

The result of our physiological experiments revealed that the rate of MDA which is a lipid peroxidation at iliç location was slightly higher than the other locations. The higher amounts of some heavy metals found at iliç location compared with the other locations were considered to be effective on MDA rate. Related with chlorophyll size, chlorophyll concentration was also lower at Erzincan location.

Many studies have also examined lipid peroxidation and chlorophyll level of certain plants by administering metals in laboratory environments alongside control groups. These studies reported significant differences in lipid peroxidation and the chlorophyll levels. As a result of these research, 
they have found significant differences at the lipid perodixation and the chlorophyll levels (Vecchia et al., 2005; Nouairi et al., 2006; Vollenweider et al., 2006; Popova et al., 2009).

\section{Conclusion}

In addition to element analyses in sediment and plant samples, some physiological features of plant samples such as lipid peroxidation, chlorophyll a, chlorophyll b and chlorophyll $a+b$ amounts were investigated. Although there were not large differences in chlorophyll amounts for all locations, lipid peroxidation activity was found to be slightly higher at iliç (Figure 3). Sediments in Karasu River had high concentrations of $\mathrm{Ni}$ and $\mathrm{Cr}$ metals. $\mathrm{P}$. australis showed hyper-accumulation for $\mathrm{Cd}$ and $\mathrm{Zn}$, therefore, it could be defined as a good biomonitoring plant. Zn level was particularly high in roots while $\mathrm{Cd}$ was higher in leaves. However, $\mathrm{K}$ was present in all parts of the plant. Lipid peroxidation was high in samples taken from iliç, and these surplus were caused by high level of lipid peroxidation.
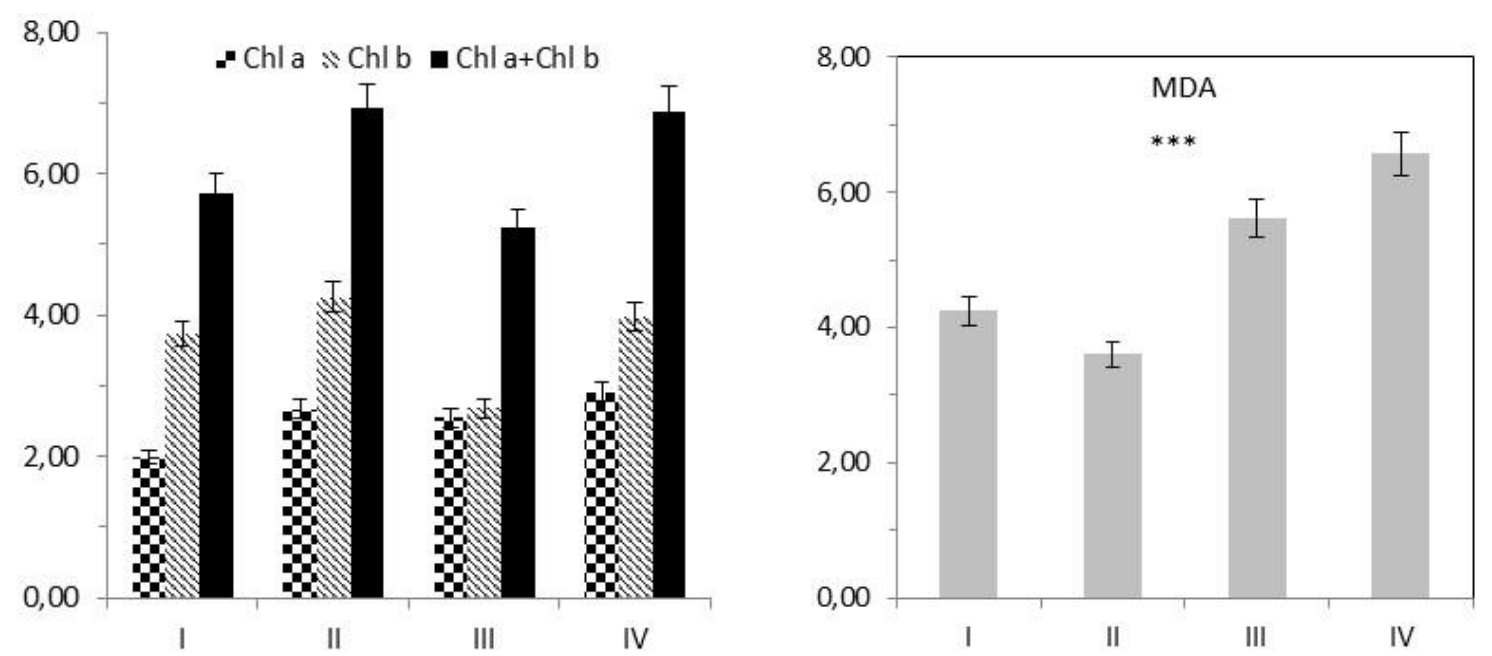

Figure 3. The lipid peroxidation $\left(\mathrm{mmol} / \mathrm{L}^{-1} \mathrm{~cm}^{-1}\right)$ and concentration of chlorophyll $\left(\mathrm{mg} / \mathrm{g}^{-1}\right)$ in $P$. australis

Table 1. The correlation between lipid peroxidation and plants.

\begin{tabular}{cc}
\hline Elements & Leaf-MDA \\
\hline $\mathrm{Zn}$ & 0,50 \\
$\mathrm{Cd}$ & 0,90 \\
$\mathrm{Cu}$ & 0,89 \\
$\mathrm{Cr}$ & 0,90 \\
$\mathrm{Ca}$ & 0,65 \\
$\mathrm{Na}$ & 0,57 \\
$\mathrm{~B}$ & 0,91 \\
\hline
\end{tabular}

\section{Acknowledgments}

This study was supported by Erzincan University BAP (12.01.16).

\section{References}

Akguc N., Ozyigit II and Yarci C. (2008), Pyracantha coccinea Roem. (Rosaceae) as a biomonitor for Cd, Pb and Zn in Mugla Province (Turkey), Pak. J. Bot., 40(3), 1767-1776.

Akguc N., Özyiğit ii, Yaşar Ü, Leblebici Z. and Yarcı C. (2010), Use of Pyracantha coccinea Roem. as a possible biomonitor for the selected heavy metals, Int. J. Environ. Sci. Tech., 7(3), 427-434. 
Aksoy A. and Oztürk M. (1996), Phoenix dactylifera L. as a Biomonitor of Heavy Metal Pollution in Turkey, J. of Trace and Microprobe Tech., 14, 605-614.

Aksoy A., Osma E. and Leblebici Z. (2012), Spreading Pellitory (Parietaria judaica L.): A Possible Biomonitor of Heavy Metal Pollution, Pak. J. Bot., 44, 123-127 (Special Issue March).

Ananieva E.A., Alexieva V.S. and Popova L.P. (2002), Treatment with salicylic acid decreases the effects of paraquat on photosynthesis, J. Plant Physiol., 159, 685-693

Anonymous. (2012), http://www.net-bilgi.com/firat-nehri-hakkinda-bilgi-net-bilgi. October 2014

Bonanno G. (2011), Trace element accumulation and distribution in the organs of Phragmites australis (common reed) and biomonitoring applications, Ecotoxicol. Environ. Saf., 74, 1057-1064.

Bonanno G. (2012), Arundo donax as a potential biomonitor of trace element contamination in water and sediment, Ecotoxicol. Environ. Saf., 80, 20-27.

Bonanno G. and Lo Giudice R. (2010), Heavy metal bioaccumulation by the organs of Phragmites australis (common reed) and their potential use as contamination indicators, Ecol. Indic., 10, 639-645.

Bose S., Vedamati J., Rai V. and Ramanathan A.L. (2008), Metal uptake and transport by Typha angustata L. grown on metal contaminated waste amended soil: An implication of phytoremediation, Geoderma, 145, 136-142.

Bragato C., Brix H. and Malagoli M. (2006), Accumulation of nutrients and heavy metals in Phragmites australis (Cav.) Trin.ex Steudel and Bolboschoenus maritimus (L.) Palla in a constructed wetland of the Venice lagoon watershed, Environ. Poll., 144(3), 967-75.

Bragato C., Schiavon M., Polese R, Ertani A., Pittarello M. and Malagoli M. (2009), Seasonal variations of Cu, Zn, $\mathrm{Ni}$ and $\mathrm{Cr}$ concentration in Phragmites australis (Cav.) Trin ex steudel in a constructed wetland of North Italy, Desalination, 246, 35-44.

Brenot A., Carignan J, France-Lanord C. and Benoît M. (2007), Geological and land use control on $\delta 34 S$ and $\delta 180$ of river dissolved sulfate. The Moselle river basin, France, Chem. Geo., 244, 25-41.

Davis P.H.(ed) (1965-1985), Flora of Turkey and the East Aegean Islands. Vol. Edinburg University Press.

Demirezen D. and Aksoy A. (2004), Accumulation of heavy metals in Typha angustifolia (L.) and Potamogeton pectinatus (L.) living in Sultan Marsh (Kayseri, Turkey), Chemosphere, 56, 685-696.

Demirezen D. and Aksoy A. (2006), Common hydrophytes as bioindicators of iron and manganese pollutions, Ecol. Indic., 6, 388-393.

Demirezen D., Aksoy A. and Uruc K. (2007), Effect of population density on growth, biomass and nickel accumulation capacity of Lemna gibba (Lemnaceae), Chemosphere, 66, 553-557.

Dhir B., Sharmila P. and Saradhi P.P. (2009), Potential of aquatic macrophytes for removing contaminants from the environment, Crit. Rev. Environ. Sci. Technol., 39(9), 754-781.

Dirilgen N. (2011), Mercury and lead: Assessing the toxic effects on growth and metal accumulation by Lemna minor, Ecotoxicol. Environ. Saf., 74, 48-54.

Duman F., Cicek M., Sezen G. (2007), Seasonal changes of metal accumulation and distribution in common club rush (Schoenoplectus lacustris) and common reed (Phragmites australis), Ecotoxicology, 16, 457-463.

Erdal S. (2012), Androsterone-induced molecular and physiological changes in maize seedlings in response to chilling stress, Plant Physiol. and Bioche., 57, 1-7.

Fargasova A. (2001), Interactive effect of manganese, molybdenum, nickel, copperl and II, and vanadiumon the fresh water alga Scenedesmusquadricauda, Bull. Environ. Contam. Toxicol., 67(5), 668-695.

Fawzy M.A., El-Sayed Badr. N., El-Khatib A. and Abo-El-Kassem A. (2012), Heavy metal biomonitoring and phytoremediation potentialities of aquatic macrophytes in River Nile, Environ. Monit. Assessment, 184, 1753-1771.

Ghosh M. and Singh S.P. (2005), A review on phytoremediation of heavy metals and utilization of its by products, Appl. Ecol. Environ. Res., 3(1), 1-18.

Glinska-Lewczuk K. and Burandt P. (2011), Effect of river straightening on the hydrochemical properties of floodplain lakes: Observations from the Lyna and Drweca Rivers, N Poland, Ecol. Eng., 37, 786-795.

Kabata-Pendias A. and Pendias H. (Eds.), (1992), Trace Elements in Soils and Plants, CRC Press, Baton Rouge, USA. 
Kacar B., Inal A. (2008), Bitki Analizlari Nobel yayın No: 1241.

Lasat M.M. (2002), Phytoextraction of toxic metals: A review of biological mechanisms, J. Environ. Qual., 31, 109120.

Leea K., Bonga Y., Leeb D., Kimc Y. and Kimd K. (2008), Tracing the sources of nitrate in the Han River watershed in Korea, using $\delta 15 \mathrm{~N}-\mathrm{NO} 3$ and $\delta 180-\mathrm{NO} 3$ values, Sci. Total Environ., 395, $117-124$.

Lesage E., Rousseau D.P.L., Meers E., Tack F.M.G. and De Pauw N. (2007), Accumulation of metals in a horizontal subsurface flow constructed wetland treating domestic wastewater in Flanders, Belgium, Sci. Total Environ., 380, 102-115.

Lichtenthaler H.K. and Buschmann C. (2001), Chlorophylls and carotenoids: measurement and characterization by UV-VIS spectroscopy, in: R.E. Wrolstad (Ed.), Current Protocols in Food Analytical Chemistry. John Wiley and Sons, New York, pp. F4.3.1-F4.3.8.

Maddison M., Soosaar K., Mauring T. and Mander U. (2009), The biomass and nutrient and heavy metal content of cattails and reeds in wastewater treatment wetlands for the production of construction material in Estonia, Desalination, 246, 120-128.

Markert B. (1993), Plant as Biomonitors: Indicators for Heavy Metals in the Terrestrial Environment, (B. Markert, ed.), VCH Weinheim, NewYork /Basel /Cambridge.

Markert B.A., Breure A.M. and Zechmeister H.G. (2003), Definitions, strategies and principles for bioindication / biomonitoring of the environment. In: (Eds.): B.A. Markert, A.M. Breure, H.G. Zechmeister, Bioindicators \& Biomonitors. Principles, Concepts and Applications, pp 3-39, Elsevier, Oxford.

Monferrán M.V., Pignata M.L. and Wunderlin D.A. (2012), Enhanced phytoextraction of chromium by the aquatic macrophytePotamogetonpusillus in presence of copper, Environ. Poll., 161, 15-22.

Mutlu S., Atici O, Esim N. and Mete E. (2011), Essential oils of catmint (Nepeta meyeriBenth.) induce oxidative stress in early seedlings of various weed species, Acta Physiol. Plant, 33, 943-951.

Mutlu S., Karadagoglu O, Atici O., Tasgin E. and Nalbantoglu B. (2012), Time-dependent effect of salicylic acid on alleviating cold damage in two barley cultivars differing at cold tolerance, Turk. J. Bot., 37, 343-349.

Nouairi I., Ammar W.B., Youssef N.B, Daoud D.B.M., Ghorbal M.H. and Zarrouk M. (2006), Comparative study of cadmium effects on membrane lipid composition of Brassica junceaand Brassica napus leaves, Plant Sci., 170, 511-519.

Obolewski K., Skorbiowicz E, Skorbiowicz M, Glinska-Lewczuk K.A. and Agnieszka Strzelczak M. (2011), The effect of metals accumulated in reed (Phragmites australis) onthe structure of periphyton, Ecotoxicol. and Environ. Saf., 74, 558-568.

Osma E., Serin M., Leblebici Z. and Aksoy A. (2012), Heavy metals accumulation in some vegetables and soils in Istanbul. Ekoloji, 21(82), 1-8.

Popova L.P., Maslenkova L.T., Yordanova R.Y., Ivanova A.P., Krantev A.P., Szalai G. and Janda T. (2009), Exogenous treatment with salicylic acid attenuates cadmium toxicity in pea seedlings, Plant Physiol. Bioch., 47,224-231.

Rengel Z. (2004), Heavy metals as essential nutrients, Heavy Metal Stress in Plants. From Biomolecules to Ecosystems, In: M.N.V. Prasad (Ed.), 2nd edn. Springer, New York, pp. 271-285.

Ross S.M. (1994), Sources and forms of potentially toxic metals in soil-plant systems. In: Ross SM (ed.), Toxic Metals in Soil-Plant Systems, Wiley, London, 3-26.

Sajidu S.M.I., Masamba W.R.L, Henry E.M.T. and Kuyeli S.M. (2007), Water quality assessment in streams and wastewater treatment plants of Blantyre, Malawi, Phy. Chem. Earth., 32, 1391-1398.

Samecka-Cymermana A. and Kempers A.J. (2004), Toxic metals in aquatic plants surviving in surface water polluted by copper mining industry, Ecotoxicol. and Environ. Saf., 59, 64-69.

Singha M., Mullerb G. and Singh I.B. (2003), Geogenic distribution and baseline concentration of heavy metals in sediments of the Ganges River, India, J of Geoche. Expl., 80, 1 -17.

Varol M. (2011), Assessment of heavy metal contamination in sediments of the Tigris River (Turkey) using pollution indices and multivariate statistical techniques, J. of Hazar. Mat., 195, 355- 364.

Varol M., Gokot B, Bekleyen A. and Şen B. (2012), Spatial and temporal variations in surface water quality of the dam reservoirs in the Tigris River basin, Turkey, Catena, 92, 11-21. 
Vecchia D.F., La Rocca N., Moro I., De Faveri S., Andreoli C. and Rascio N. (2005), Morphogenetic, ultra structural and physiological damages suffered by submerged leaves of Elodea canadensis exposed to cadmium, Plant Sci., 168, 329-338.

Vollenweider P., Cosio C., Günthardt-Goerg M.S. and Keller C. (2006), Localization and effects of cadmium in leaves of a cadmium-tolerant willow (Salix viminalis L.) Part II Microlocalization and cellular effects of cadmium, Environ. Exp. Bot., 58, 25-40.

Vymazal J., Kropfelova L., Svehlac J., Chrastny V. and Stichova J. (2009), Trace elements in Phragmites australis growing in constructed wetlands for treatment of municipal wastewater, Ecol. Eng., 35, 303-309.

Vymazal J., Svehla J., Kropfelova L. and Chrastny V. (2007), Trace metals in Phragmite saustralis and Phalaris arundinacea growing inconstructed and natural wetlands, Sci. Total Environ., 380, 154-162.

Weis S.J. and Weis P. (2004), Metal uptake, transport and release by wetland plants: implications for phytoremediation and restoration, Environ. Inter., 30, 685-700.

Xiao-Dong L., Cong-Qiang L., Xiao-Long L. and Li-Ran Bao. (2011), Identification of dissolved sulfate sources and the role of sulfuric acid in carbonate weathering using dual-isotopic data from the Jialing River, Southwest China, J. of Asian Earth Sci., 42, 370-380.

Yasar U., Ozyigit II. and Serin M.(2010), Judas tree (Cercis siliquastrum L. subsp. siliquastrum) as a possible biomonitor for $\mathrm{Cr}$, Fe and $\mathrm{Ni}$ in Istanbul (Turkey), Rom. Biotech. Lett., 15(1), 4983-4992.

Zayed A.M. and Terry N. (2003), Chromium in the environment: Factors affecting biological remediation, Plant Soil, 249, 139-156. 